DOI: $10.2478 / \mathrm{v} 10014-011-0014-8$

COBISS Code 1.01

Agrovoc descriptors: women, role of women, social consciousness, social structure, social values, social groups, value systems, decision making, management, human behaviour, incentives, plant production, potatoes, solanum tuberosum

Agris category code: E50, E20

\title{
Rural women's attitudes toward their participation in the decision-making process and production of potato crops in Shoushtar, Iran
}

\author{
Sayedeh Somayeh MOSAVI ${ }^{1}$, Ahmad Reza OMMANI ${ }^{2}$ and Mohammad Sadegh ALLAHYARI ${ }^{3 *}$
}

Received: August 18, 2011; accepted: September 20, 2011.

Delo je prispelo 18. avgusta 2011, sprejeto 20. septembra 2011.

\begin{abstract}
The main purpose of this study was to evaluate rural women's' attitudes to their participation in the decision-making process and production of potato crops in Shoushtar, Iran. It is an applied research for which a descriptive-correlation method is chosen. Using the documentary study methodology and field study, required data have been collected and then described in terms of frequency, percentage and standard deviation. According to the size of population, the number of samples was determined to be 288 people. According to the results, there is a significant correlation between the level of attitude and participation in the decision-making process and production. Also, the rural women's' higher levels of attitude to their participation in decision-making processes regarding crop production and farm work improves their selfconfidence, sense of independence and power and, therefore, encourages them to participate in those activities effectively.
\end{abstract}

Key words: participation, rural women, decision-making, attitude, potato

\author{
IZVLEČEK \\ DRŽA PODEŽELSKIH ŽENSK GLEDE \\ SODELOVANJA PRI ODLOČANJU IN \\ PRIDELOVANJU KROMPIRJA V SHOUSHTAR-JU, \\ IRAN
}

Cilj raziskave je ovrednotiti držo podeželskih žensk do njihove udeležbe $\mathrm{v}$ procesu odločanja in pridelave krompirja $\mathrm{v}$ Shoushtarju v Iranu. Gre za aplikativno raziskavo, pri kateri je uporabljena deskriptivno-korelacijska metoda. Želeni podatki so bili zbrani s pomočjo študija metodološke literature in terenske raziskave, predstavljeni pa so s frekvencami, odstotki in variancami. Glede na velikost populacije je bil izbran vzorec, ki je zajemal 288 ljudi. Rezultati so nakazali močno povezavo med odnosom do dela ter participacijo $\mathrm{v}$ procesih odločanja in pridelave. Rezultati so prav tako pokazali, da boljša drža žensk do njihove participacije v procesu odločanja glede pridelovanja in dela na kmetiji izboljša njihovo samozavest, občutek neodvisnosti in moči ter jih tako spodbuja k učinkovitemu sodelovanju v teh dejavnostih.

Ključne besede: udeležba, podeželske ženske, odločanje, drža, krompir

\section{INTRODUCTION}

In many societies rural women serve as the main work force involved in agricultural activities. These activities may include farm works, from planting to harvest, animal husbandry and some marketing. Involvement of women in the labor market is believed to be one of the main indicators of a country's development that reflects women's interests in different economic and social activities. The extent of rural women activity is far more influenced by economic, social, cultural and ecological factors than it is in case of men. Rural women, either directly or with indirect engagement in agricultural

\footnotetext{
1,2 Department of Agricultural Management, Shoushtar Branch, Islamic Azad University, Iran

3 Department of Agricultural Management, Rasht Branch, Islamic Azad University, Iran

*Email: allahyari@iaurasht.ac.ir
} 
activities, are considered to have significant potential effects on a society.

The concept of participation and cooperation is an old one which has originated from public affairs management and religious beliefs. The concept is mentioned in Islamic teachings as "Shora". The managers have been required clearly by the Holy Quran to consult with others before making decisions about the issues which need research and investigation.

In many countries, women make up $60-80 \%$ of workforces involved in the agriculture sector. Provided that $75-90 \%$ of the population are dependent on agriculture in the Third World countries, a great proportion of women are involved in agricultural activities. Women not only prepare all, or most of the family food requirement, but also play a significant role in production of those kinds of commercial products which are exclusively produced by men (Liming, 1991).

As the most critical products in a society, agricultural products play a significant role in economic development and food security. The world population growth and overuse of cultivable lands have led farmers to improve their efficiency and performance instead of expanding the cultivated land area. In this regard, farm management plays an important role: it is aimed at optimizing the use of resources, improving the performance and, as a result, improving the economic efficiency of production. The purpose of farm management is to improve resource-use efficiency by understanding the possibilities and/or limitations of production (Zaree, 2000).

The family is considered to be the main social unit in which one experiences the first stages of socialization and also the first instances of sexual inequalities. The kind of relationship between parents, their share of economic, social, cultural and symbolic resources makes an unequal image of different sexes in one's mind and gradually this inequality seems natural to a normal person. If the traditional sexual patterns are accepted by the woman, two consequences arrive: first, the woman accepts and affirms her low position and the inequality and second, she as the main person involved in the children's socialization, passes the belief on, to the next generation. Both the consequences maintain and reproduce the inequality inside the family and then in the society (Garousi, 2005).

Multiple responsibilities of women, as a result of their activities out of the home, have doubled their expected tasks but have not led to an improvement in their rights. In other words, an increase in their participation has reduced their leisure time and well-being (Cowan, 1983). Classic conservative sociologists believe that women should have a defined fixed role in the family and they should not participate in other activities outside of the home. They have a God-given responsibility to take care of their husbands and children (Saroukhani, 1991).

Housewives therefore, always experience a series of economic or social dependencies on men. However, deep economic and social changes occurred during the industrial revolution, leading to definition of new values and norms and destruction of old traditional patterns that used to limit women's activities to the family and inside the homes enabling women to have their opinions about subjects out of their families and homes and, thus, to make their own decisions. Women's employment, therefore, helped them to acquire their own right to participate and to make decisions about their families (Bagheri et al., 2008).

The important roles of women in the processes of production and marketing have always been ignored by the development designers. They are not included in the educational programs regarding new planting strategies, food stuff production, and use of technology in managing the workforce, animal husbandry, small industries, marketing and other services. Official credits are rarely given to women and often the men are those who can apply for cooperatives and benefit the loans (Dulyapach, 1985).

According to the Agricultural Research Institute, men mainly make decisions about farming and women have more important roles in managing the family (Anony, 1991). Researchers have found that in South Asia, women from big landowner families who supervise daily work processes in the farms tend to give information to the farmer women that are beneficial for both sides. Women landowners may serve as good contact farmers. Therefore, participation of rural women in decision- making processes is not an inevitable easy to accept fact in many areas and may conflict benefits of many rural men and women (FAO, 1991).

One may consider three levels of women's participation and decision-making in farming activities:

- Social and national levels in which their role in production of commercial non-commercial products are determined.

- Family level, in which they prepare food, clothes, fuel and care for the elderly.

- Intra-generation level in which they satisfy children's educational and emotional demands (Suman, 2008). In a research entitled 'Evaluating the economic 
participation of rural women in Fars province, Iran', Lahsaii Zadeh et al. (2005) suggested that there is a reverse relationship between the level of women's education and their economic participation. Also, their participation is improved as they become older. Their participation is also reduced when the men's education and income level increase. Using mass media, men's perception of women's economic role and women's self-confidence, can explain $33.8 \%$ of changes in the dependent variables.

- In a research entitled 'Factors influencing women's empowerment', Rahnavard and Hosseini (2008) found that the level of women's empowerment exists at a moderate level and the results of factor analysis highlights following factors: 1) management attitude;
2) group structure; 3) inter-group values; and 4) information communication. Furthermore, regression analysis shows that only the first three factors determine $63 \%$ of variability in women's empowerment.

The main purpose of this study was to evaluate rural women's' attitudes to their participation in the decisionmaking process and production of potato crops in Shoushtar township, Iran. The objectives of the study were as follows:

1. Describe socio-personal characteristics of women who participated in potato production,

2. Determine the level of women's attitude to participation in decision-making and production

\section{MATERIALS AND METHODS}

The researchers conducted a study using a survey research design and it was descriptive-correlation according to the methodology. Required data is collected using documentary and field studies and obtained results were described in terms of frequency, percent, mean score and standard deviation. The target population involves all girls and women over 15 , living in Shoushtar Township rural areas who participating in potato crop production, from the planting to the harvesting. Shoushtar Township is made up of two regions, six rural districts and 196 villages. The population of women involved in potato production is 1150 people who are considered as target population which 288 samples were selected randomly. The data-collection instrument was a closed-form questionnaire. A panel of experts reviewed the instrument for face, content, and constructs validity. A pilot study was conducted to establish the reliability of the instrument. Reliability coefficient (Cronbach's alpha) for the competencies was 0.81 . All members of the population were interviewed by a researcher-designed questionnaire to solicit attitudes toward their participation in the decision-making process and production of potato crops.

Descriptive statistics such as mean score, percent, standard deviation and Spearman rank correlation were used to analyze this survey data.

\section{RESULTS}

The data collected in the study include the subject's age, education, income, job, number of family members, work history, owned land area, level of technical knowledge and level of attitude, but the values regarding level of education, number of family members and level of attitude are mentioned here:
According to the results, $25.3 \%$ of women ( $\mathrm{n}=73$ ) were illiterate, $58.7 \%(\mathrm{n}=169)$ were able to read and write, $8.7 \%(\mathrm{n}=25)$ have high school diploma and 7.3\% $(\mathrm{n}=21)$ have higher diploma degrees (table 1).

Table 1: Distribution of women participating in potato production according to level of education ( $\mathrm{f}=$ frequency).

\begin{tabular}{lccc}
\hline Level of education & f & percent & cumulative percent \\
\hline Illiterate & 73 & 25.3 & 25.3 \\
Able to read and write & 169 & 58.7 & 84.0 \\
High school diploma & 25 & 8.7 & 92.7 \\
Higher that diploma & 21 & 7.3 & 100.0 \\
Total & 288 & 100.0 & \\
\hline
\end{tabular}

According to the results, the number of family members of the subjects is as follows: $77.1 \%(\mathrm{n}=222)$ were in $3-6$ member families, $20.5 \% \quad(\mathrm{n}=59)$ in $6-10$ member families and $2.4 \%(n=7)$ in $10-13$ member families. The smallest families have 3 members and the biggest ones have 13 members (table 2). 
Table 2: Distribution of women participating in potato production according to the number of family members ( $\mathrm{f}=$ frequency).

\begin{tabular}{lccc}
\hline Number of family members & f & Percent & cumulative percent \\
\hline $3-6$ members & 222 & 77.1 & 77.1 \\
6-10 & 59 & 20.5 & 97.6 \\
$10-13$ & 7 & 2.4 & 100.0 \\
Total & 288 & 100.0 & \\
\hline
\end{tabular}

Representative: 5 maximum: 13 minimum: 3

Twelve statements were prepared to evaluate the women's attitude to participation in decision-making and production and they were asked to give their desired answers. Table 3 shows the frequency and percentages of the answers. The answers were given values from 1 to 5 to group the women according to their attitude, and everyone's results were divided by 12 . If the resultant number was 1 , then it was mentioned in a very low attitude group, if the number was from 2 to 3, it was mentioned in an average attitude group, if the number was from 3 to 4 , it was mentioned in a high attitude group and in a very high attitude group if the resultant number was 4 to 5 .

Table 3: Distribution of women participating in potato production

\begin{tabular}{|c|c|c|c|c|c|c|c|c|c|c|c|c|c|}
\hline \multirow{2}{*}{ Z } & \multirow[t]{2}{*}{ Statements } & \multicolumn{2}{|c|}{$\begin{array}{l}\text { Strongly } \\
\text { agree }\end{array}$} & \multicolumn{2}{|c|}{ Agree } & \multicolumn{2}{|c|}{ Undecided } & \multicolumn{2}{|c|}{ Disagree } & \multicolumn{2}{|c|}{$\begin{array}{l}\text { Strongly } \\
\text { disagree }\end{array}$} & \multirow[t]{2}{*}{$\mathrm{M}$} & \multirow[t]{2}{*}{ SD } \\
\hline & & $\mathrm{f}$ & $\%$ & $\mathrm{f}$ & $\%$ & $\mathrm{f}$ & $\%$ & $\mathrm{f}$ & $\%$ & $\mathrm{f}$ & $\%$ & & \\
\hline 1 & $\begin{array}{l}\text { Does not improve self-confidence in } \\
\text { women }\end{array}$ & 61 & 21.2 & 41 & 14.2 & 41 & 14.2 & 56 & 19.4 & 7 & 2.4 & 3.60 & 1.09 \\
\hline 2 & $\begin{array}{l}\text { Does not help family members to } \\
\text { cooperate with each other }\end{array}$ & 52 & 18.1 & 38 & 13.2 & 38 & 13.2 & 41 & 14.2 & 17 & 5.9 & 3.58 & 1.11 \\
\hline 3 & $\begin{array}{l}\text { Encourages women to accept farm } \\
\text { management responsibilities }\end{array}$ & 77 & 26.7 & 83 & 28.8 & 29 & 10.1 & 55 & 19.1 & 13 & 4.5 & 3.64 & 1.19 \\
\hline 4 & $\begin{array}{l}\text { Is not a good method to improve } \\
\text { performance and the quality of potato }\end{array}$ & 27 & 9.4 & 56 & 19.4 & 56 & 19.4 & 52 & 18.1 & 28 & 9.7 & 3.24 & 1.14 \\
\hline 5 & $\begin{array}{l}\text { Improves women position in the family } \\
\text { and society }\end{array}$ & 21 & 7.3 & 114 & 39.4 & 75 & 26 & 90 & 13.3 & 19 & 6.6 & 2.98 & 1.07 \\
\hline 6 & $\begin{array}{l}\text { Helps women get access to the credits } \\
\text { and loans }\end{array}$ & 19 & 6.6 & 56 & 19.4 & 67 & 23.3 & 147 & 51 & 20 & 6.9 & 2.60 & 1.01 \\
\hline 7 & $\begin{array}{l}\text { Does not help reduce women's } \\
\text { dependence on men. }\end{array}$ & 50 & 17.4 & 39 & 13.5 & 39 & 13.5 & 56 & 19.4 & 36 & 12.5 & 3.27 & 1.30 \\
\hline 8 & Helps avoid time and money loss & 13 & 4.5 & 58 & 20.1 & 79 & 27.4 & 111 & 38.5 & 39 & 13.5 & 2.59 & 1.05 \\
\hline 9 & $\begin{array}{l}\text { Does not help women's ideas and role } \\
\text { to be noticed }\end{array}$ & 35 & 12.2 & 31 & 10.8 & 31 & 10.8 & 69 & 24 & 44 & 15.3 & 3.07 & 1.31 \\
\hline 10 & $\begin{array}{l}\text { Helps family get more income and } \\
\text { benefits }\end{array}$ & 20 & 6.9 & 35 & 12.2 & 35 & 12.2 & 137 & 47.6 & 40 & 13.9 & 2.57 & 1.15 \\
\hline 11 & Helps reform old traditional thoughts & 7 & 2.4 & 41 & 14.2 & 43 & 14.9 & 118 & 41.0 & 63 & 21.9 & 2.39 & 1.11 \\
\hline 12 & $\begin{array}{l}\text { Helps women accept the } \\
\text { responsibilities }\end{array}$ & 39 & 13.5 & 46 & 16 & 29 & 10.1 & 100 & 34.7 & 62 & 21.5 & 2.69 & 1.36 \\
\hline
\end{tabular}

( $\mathrm{f}=$ frequency).

The results shows that $39.9 \%(\mathrm{n}=115)$ of people are in an average attitude group and $60.1 \%(\mathrm{n}=173)$ in a high attitude group (table 4).
According to each variable scale, the correlation coefficient was calculated to determine the correlation between the variables and the degree of significance. 
Rural women's attitudes toward their participation in the decision-making process and production of potato crops...

Table 4: Distribution of women participating in potato crop production according to level of attitudes ( $\mathrm{f}=$ frequency).

\begin{tabular}{lccc}
\hline Level of attitude & f & Percent & Cumulative percent \\
\hline Very low attitude & 0 & 0 & 0 \\
Low attitude & 0 & 0 & 0 \\
Average attitude & 115 & 39.9 & 39.9 \\
High attitude & 173 & 60.1 & 100 \\
Very high attitude & 0 & 0 & 0 \\
Total & 288 & 100.0 & \\
\hline
\end{tabular}

Table 5: Results of correlation analysis

\begin{tabular}{|c|c|c|c|c|c|}
\hline \multirow{2}{*}{$\begin{array}{l}\text { First variable } \\
\text { Variable }\end{array}$} & \multicolumn{3}{|c|}{ Second variable } & \multirow[t]{2}{*}{$\mathrm{r}_{\mathrm{s}}$} & \multirow[t]{2}{*}{$\mathrm{p}$} \\
\hline & Scale & variable & scale & & \\
\hline Education & ordinal & Participation $^{1}$ & ordinal & $0.385^{* *}$ & 0.01 \\
\hline Number of family members & interval & Participation & ordinal & -0.104 & 0.39 \\
\hline Attitude toward production activities & ordinal & Participation & ordinal & $0.450^{* *}$ & 0.01 \\
\hline
\end{tabular}

There was a significant relationship between the rural women's education level and their degree of participation in decision-making and in potato production. According to the Spearman rank correlation value of 0.385 for the two variables and 0.01 level of significance, there should be a significant correlation between them, therefore the supposed assumption is verified.

There is also a significant relation between the number of family members and the women's participation in decision-making processes and producing of potato crops. According to the Spearman rank correlation value of -0.104 , between the two variables there was no significant correlation between the variables $(p=0.39)$, therefore, the supposed assumption is rejected.

According to the results, there was a significant relation between women's levels of attitudes toward production activities and participation. According to the Spearman rank correlation $\left(\mathrm{r}_{\mathrm{s}}=0.450\right)$ between the two variables there was a significant relationship, therefore the supposed assumption is verified.

\section{DISCUSSION AND CONCLUSIONS}

It was found that there was a significant correlation between the rural women's level of attitude toward production activities and their participation in potato crop production. The results obtained by other researchers like Lahasai Zadeh et al (2005), Rahnavard and Hosseini (2007) and Maghsoudi et al. (2005) also support these findings. Therefore, attitude-derived faculties like the senses of power, dignity and independence are improved in the women and these bring them a more strong self-confidence and also encourage them to participate in different economic activities. Jarollahi (1992) in a research called "woman's employment in Iran" states that social, economical and cultural changes of Iranian society has changed women's social conditions and consequently their decision making power throughout history so that when society put importance on women's social condition and status, she was able to initiate and by decreasing its importance, decision making power has decreased, too. Romito and Volpato (2005), Also, state that lack of consideration to their needs, sexual orientation in designating responsibilities as limited access to power resources, options, designation, promotions and influence on top organization hierarchy, would lead to their deprivation of conditions and job's options and decrease in motivation.

Rural women either directly or in terms of help to Agriculture part are considered significant potentials. But their roles have been affected more by different social, economical, cultural and ecological conditions and factors. So, attitudes indexes such as power, status and independence would be reinforced in women in order to participate at different affaires especially at productive activities by more self-confidence. 
According to the present study results, educational and cultural programs are suggested to improve rural men's perception of women's capabilities and their significant roles. Also, it is suggested to prepare required facilities to balance different economic, social and cultural roles of rural men and women. It is also recommended to consider suitable positions for rural women's participation while developing and designing agricultural programs. Building women groups and help-committees inside rural societies are assumed to be basic and practical solutions in this regard.

\section{REFERENCES}

Anony, M. 1991. Final report on women's role in integrated farming system research in Supahan Buri Province. Department of Agriculture, Kasetsart University, Department of Agriculture, Kasetsart University, Office of Agricultural Economics, Thailand.

Bagheri, M; Moltafet, H. and Sharifian, H. 2008. Evaluating the effects of women employment on the pyramid of power in the family. Journal of Family Research. 5(18): 247-252.

Cowan, A. 1983. More work for mother. New York: Basic Book.

Dulyapach, P. 1985. Thai women in Agriculture and rural development. FAO Regional Office for Asia and the Pacific, Bangkok, Thailand, p: 55.

FAO (Food and Agriculture Organization of the United nations) 1999. Gender issues in land tenure. High Level Consultation on Rural Women and Information. Rome 46 October.

Garousi, S. 2005. Evaluating the effects of traditional patterns on sexual inequality, a case study in Kerman and related rural area. Ph.D. Dissertation, College of Social Sciences, University of Shiraz, Iran.

Jarollahi, A. 1992. Woman's employment in Iran. Journal of Social Sciences. 8: 201-220. (In Persian).
Lahasai Zade, A. 2005. Evaluating the economic participation of rural women. Journal of Iranian Sociology, 5(4): 3-31. (In Persian)

Liming, R. 1991. Women participation in rural cooperatives. Tehran, Banoo Publication.

Maghsoudi, T.; Iravani, H.; Movahed Mohammadi, H. and Asadi, A. 2005. Regression analysis of factors influencing potato planting stability in Fereidunshahr. Journal of Rural Development, 3(35):153- 169.

Rahnavard, F; Hosseini, N. 2007. Factors influencing women empowerment. Journal of Women Research, 1(20): 137144.

Romito, P. and Volpato, C. 2005. Women inside and outside academia: a struggle to access knowledge, legitimacy and influence. Social Science Information, 44(1): 41-63.

Saroukhani, B. 1991. Family sociology. Tehran, Soroush Publication.

Suma, M. 2008. Participation of rural women under household and farm activities. Indian Journal of Agricultural Research, 42(1): 37-41.

Zaree, A. 2000. Farm management in management structural system. Proceedings of $4^{\text {th }}$ Iranian national productivity congers Tehran: Iranian National Productivity Organization, p: 211. 